\title{
REPORT ON THE WORKSHOP AND REGULAR MEETING OF THE IMODE-CKD AND BCMOLMED MARIE CURIE TRAINING AND RESEARCH PROGRAMS (Skopje, March 2015)
}

\section{Magdalena Krochmal $^{1}$, Katryna Cisek ${ }^{2}$, Katerina Markoska ${ }^{3}$, Goce Spasovski ${ }^{3}$ and Antonia Vlahou ${ }^{1}$}

${ }^{1}$ Biotechnology Division, Biomedical Research Foundation Academy of Athens, Soranou Ephessiou 4, 115 27, Athens, Greece

${ }^{2}$ Mosaiques Diagnostics GmbH, Rotenburger Straße 20, D-30659, Hannover, Germany

${ }^{3}$ University Department of Nephrology, Medical Faculty, Sts. Cyril and Methodius University, Vodnjanska 17, 1000, Skopje, R. Macedonia

Corresponding Author: Prof. Goce Spasovski, University Department of Nephrology Medical Faculty University of Skopje, Vodnjanska 17, 1000 Skopje, R. Macedonia; Phone: +389 702682 32; Fax: +389 (0)2 32209 35;

E-mail: spasovski.goce@gmail.com

\begin{abstract}
A Workshop and Regular Meeting of the Marie Curie Training and Research Programs iMODECKD (Identification of the Molecular Determinants of established Chronic Kidney Disease) and BCMolMed (Molecular Medicine for Bladder Cancer) was held from 20-22 March at the Macedonian Academy of Science and Arts (MASA). The meeting was hosted by the participating center University of Skopje (SKO) - Goce Spasovski and MASA - Momir Polenakovic (R. Macedonia). The representative from MASA proteomic research center - Katerina Davalieva (R. Macedonia) had presentation on proteomic research in prostate cancer (PCa). 40 researchers from 13 different countries participated at the meeting. The Workshop was devoted on "Chronic Kidney Disease: Clinical Management issues", and consisted of 15 oral presentations given by nephrologists and experts in the field of CKD. Raymond Vanholder (Belgium) - past president of ERA-EDTA had a keynote lecture on "CKD: Questions that need to be answered and are not (or at least not entirely)". The workshop continued in four sessions with lectures from Alberto Ortiz (Spain), Olivera Stojceva-Taneva (R. Macedonia), Dimitrios Goumenos (Greece), Joachim Beige (Germany), Marian Klinger (Poland), Goce Spasovski (R. Macedonia), Joachim Jankowski (Germany), Adalbert Schiller (Romania), Robert Johnson (USA), Franco Ferrario (Italy), Ivan Rychlik (Czech Republic), Fulvio Magni (Italy) and Giovambattista Capasso (Italy), all covering a training theme. Within the meeting there were two lectures on complimentary skills for ethics in science and career advancement from two principal investigators Goce Spasovski (R. Macedonia) and Joost Schanstra (France). During the Regular Meeting, 13 PhD students i.e. Early Stage Researchers and one Experienced Researcher from both Programs presented their work and progress within iMODE-CKD and BCMolMed projects. This meeting was a great opportunity to exchange experience and ideas in the field of systems biology approaches and translational medicine and planning future collaboration.
\end{abstract}

Key words: prostate tumor, system biology, translational medicine, urinary proteomics

A Workshop and Regular Meeting of the Marie Curie Training and Research Programs iMODE-CKD (Identification of the Molecular Determinants of established Chronic Kidney Di- sease; http://www.imodeckd.org/.) and BCMolMed (Molecular Medicine for Bladder Cancer; http://www.bcmolmed.org/.) took place at the Macedonian Academy of Sciences and Arts, 
Skopje, Republic of Macedonia, 20-22 March 2015 (local hosts: Prof. Spasovski and Ms. Markoska). In brief, the iMODE-CKD program aims at integration of various "omics" datasets using systems biology and bioinformatics approaches in order to identify putative biomarkers of chronic kidney disease diagnosis and progression. BCMolMed similarly applies systems biology approaches with the main objecttive to increase understanding of bladder cancer invasiveness. Both programs share the same training objectives, i.e. training young investigators in systems biology approaches as applied to biomarker and therapeutic target discovery while increasing their multidisciplinary communication skills and working experience in academic and industrial settings.

A total of 40 researchers attended the meeting from over 13 countries (Fig. 1). The purpose of the Workshop was to present current clinical management issues related to chronic kidney disease. A total of 15 oral presentations were given by renowned nephrologists and experts in multiple issues related to CKD. In addition, two presentations on complimentary skills (ethics in science and career advancement) were given by iMODE-CKD principle investigators.

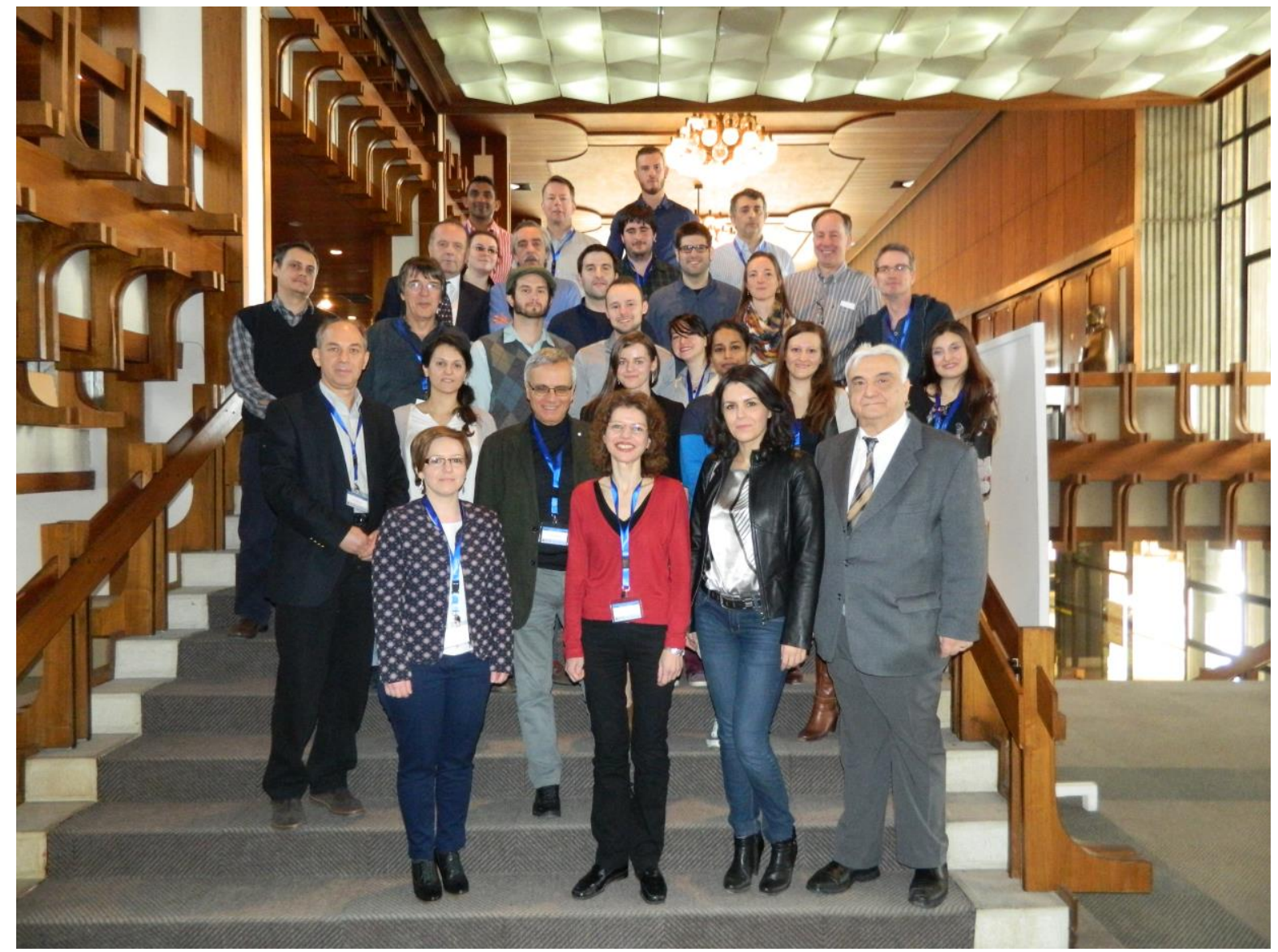

Figure 1 - iMode-CKD and BCMolMed consortium members

The meeting was opened by Goce Spasovski (R. Macedonia) from the hosting institution. In his brief introduction he presented the Research Centre for Genetic Engineering and Biotechnology (RCGEB) and introduced local hosts from the organizing committee, Momir Polenakovic, Katerina Davalieva and Katerina Markoska.

A presentation by Katerina Davalieva ( $\mathrm{R}$. Macedonia) was then given, on proteomics re- search in prostate cancer $(\mathrm{PCa})$, as applied in ongoing projects in RCGEB. Main scope of their research is the identification of biomarkers for PCa detection from urine samples by 2-dimensional electrophoresis, generating a large number of biomarkers candidates for $\mathrm{PCa}$, complementing existing lists from the literature. Nevertheless, inconsistencies in sample collection, storage and processing methods as well as high inter- and intra-variability of body fluid 
samples impede data comparability and selection of biomarkers to be applied in clinical trials.

The Saturday training session started with Raymond Vanholder's (Belgium) presentation focusing on methods to decrease uremic toxins in dialysis patients. To remove middle molecules ( $\beta 2$-microglobulin) and protein-bound compounds (indoles, phenols), numerous solutions such as improvements in dialysis conditions, therapeutic treatments, and stem cells implanttation are currently explored. Progress in extracorporeal toxin removal can be achieved by increase in dialysis time (with higher dialysate flow and membrane surface area), use of novel matrix membranes (e.g. dual layer hollow fibers) or artificial kidney. Additional approaches include targeting uremic toxins throughout the intestine, by diet supported with therapeutics (prebiotics, probiotics, symbiotic, sorbents) and modification of metabolism.

Alberto Ortiz (Spain) covered issues related to the ever increasing prevalence of CKD. With the hypothesis that the "physiological" decrease in renal function is in fact an undiagnosed CKD condition, he proposed that novel biomarkers should focus on earlier detection of renal function loss. He also underlined the problem of CKD unawareness due to limited patient screening and lack of satisfactory diabetic kidney disease treatments, which is known to be the major contributor to ESRD (End Stage Renal Disease) occurrence.

Olivera Stojceva-Taneva (R. Macedonia) highlighted the need of accurate glomerular filtration rate (GFR) measurement and its importance in current diagnosis, prognosis and treatment of CKD patients. The level of GFR is used for clinical assessment of kidney function and disease severity, and it can be measured either by exogenous marker clearance (mGFR) or estimated based on blood creatinine level (eGFR). However, both forms of measurements have drawbacks, i.e. mGFR is measured with inulin which is an invasive marker and its clearance is altered by renal handling or extrarenal metabolism, whereas accuracy of eGFR is questioned due to high variability of serum creatinine levels, further underscoring the need for novel biomarkers.

Dimitrios Goumenos (Greece) explored the topic of proteinuria and its relation to chronic kidney disease progression emphasizing the need for novel biomarkers for identification of kidney scarring. Based on the observed renal fibrosis, the assumption that anti-cytokines or antifibrotic markers could reflect the early changes leading to interstitial fibrosis was supported.

Joachim Beige (Germany) deliberated over the complexity of CKD and its prevention (Fig. 2 ). Methods of prevention vary depending on patients' condition and include basic diet adjustments, smoking avoidance, physical activity (primary prevention) or treatment of secondary phenomena that coexist with kidney diseases such as acidosis and hypertension (secondary prevention). Nevertheless, some questions regarding CKD progression remain unanswered, thus prevention methods should be tailored for individual patients, based on their clinical parameters.

Marian Klinger (Poland) characterized hypertension as an important factor in the mechanism of glomerulosclerosis, which in the majority of cases is connected with ischemic nephropathy among the elderly population. As proteinuria in not the only factor of CKD progresssion, he outlined the necessity of blood pressure monitoring and focusing on individual patient needs when making a clinical judgement and deciding on a diagnosis and further treatment.

Goce Spasovski presented on the topic of cardiovascular disease (CVD) in CKD, describing mineral and bone disorders. The abnormalities in calcium and phosphate homeostasis lead to hormonal (PTH secretion) and mineral (bone resorption) changes, which contribute to CVD development, increased morbidity and mortality. He investigated the use of bone biopsy for renal osteodystrophy diagnosis and methods of calcium administration in CVD treatment.

CKD-related cellular and molecular mechanisms as well as major disease complications were described in detail by Joachim Jankowski (Germany). Known cellular events that are present in CKD pathophysiological pathways include mesangial and fibroblast activetion, monocyte and macrophage differentiation, and T-cell activation. Decreased kidney function is often accompanied by complications such as anemia, CVD, mineral and bone disorders and dyslipidemia, and therefore, a broad understanding of CKD mechanisms is crucial in disease prevention and treatment. 


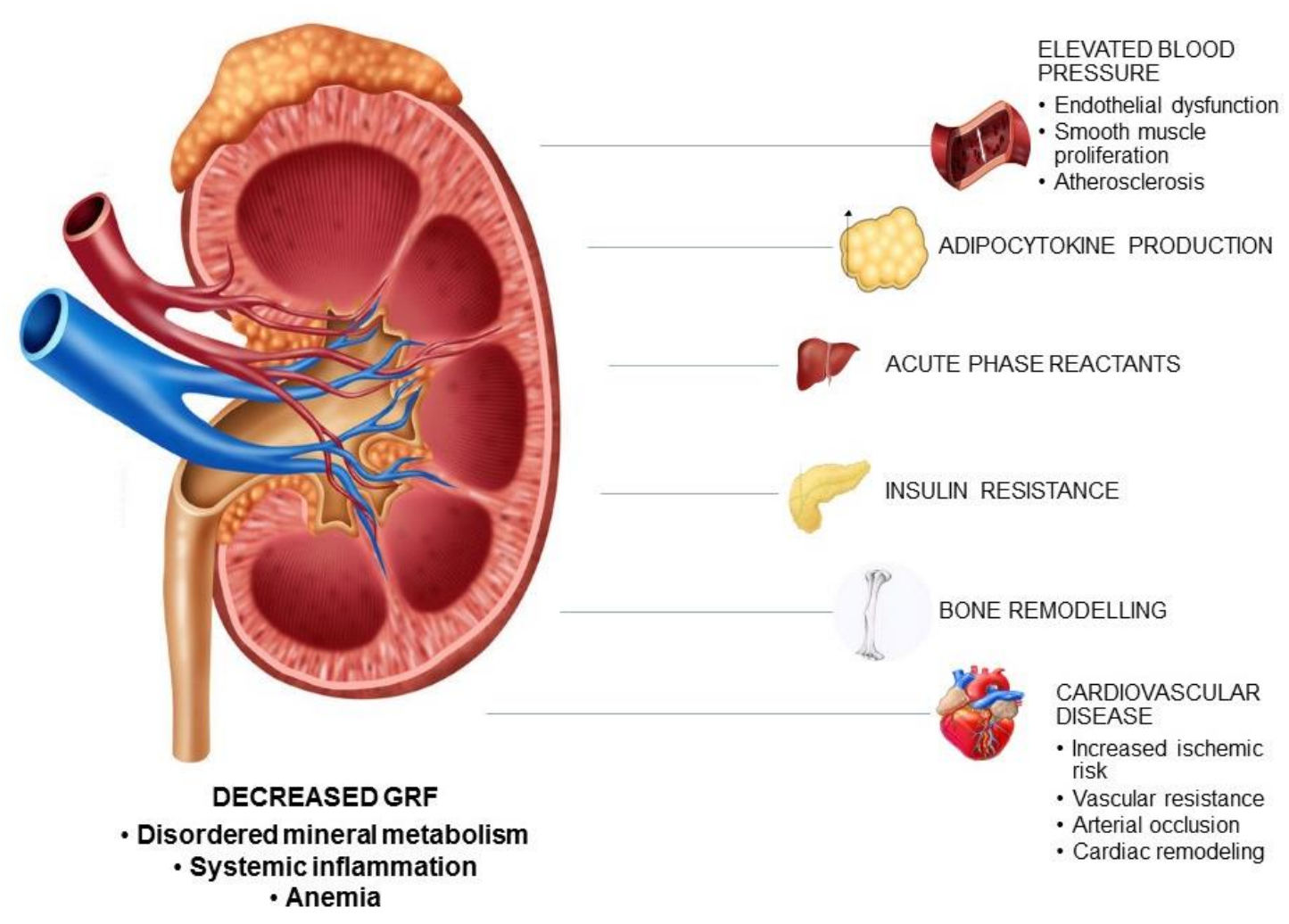

Figure 2 -Complex pathogenesis of chronic kidney disease (CKD)

Adalbert Schiller (Romania) presented novel therapeutic targets aimed at inhibition of fibrotic and inflammatory factors, namely USF $1 / 2$, TGF- $\beta$, CTGF that can be achieved by BMP-7 receptor stimulation, miR-192 downregulation, and inhibition of NF-kB pathway. Cytotoxic effects of oxidative stress can be managed by $\mathrm{NADPH}$ oxidase suppression or induction of $\mathrm{Nu}-$ clear factor (erythroid-derived 2)-like 2 (Nrf2). $\mathrm{He}$ also reported ongoing research studies that are designed to slow down CKD progression. Furthermore, he described prospects and challenges of regenerative medicine in kidney disease treatment.

Robert Johnson (USA), a representative of the research-intensive biopharmaceutical company AbbVie, presented the modern drug discovery pipeline for 'next-generation' therapeutics development. This (pipeline) incorporates modern genomics, proteomics and metabolomics platforms that allow high-throughput molecular screening of biological samples and provide promising findings. Novel hypotheses are validated on large cohorts, followed by extensive clinical assessments and multi-year follow-ups before moving onto clinical trials. $\mathrm{Fu}-$ ture diagnostics and therapies will be crafted to meet each individual patients' needs.

Renal biopsy - the current "gold standard" for CKD diagnosis - was presented by Franco Ferrario (Italy). He underscored the importance of histological assessment due to the variability of lesions present in glomerular disease. Dr Ferrario has developed a training tool on $\mathrm{CKD}$ histopathology via posting images of kidney biopsies in the password-protected area of the iMODECKD website. Nowadays, kidney biopsy is still considered the ultimate test for accurate diagnosis, prognosis and selection of proper treatment.

The subsequent speech of Ivan Rychlik (Czech Republic) continued on the topic of renal biopsy with focus on the occurrence of non-diabetic renal disease (NDRD) among diabetic patients. The incidence of NDRD, that can have both glomerular and non-glomerular origin, is very high in type 2 diabetic patients, but only patients with atypical presentations undergo histological examination. For this reason, there is a need for a unified policy regarding patient classification.

Andrew Smith, who substituted his supervisor Fulvio Magni (Italy), spoke about mass 
spectrometry imaging (MSI), a technique that combines the detection of different classes of analytes and their spatial distribution that can be used for advanced tissue analysis. When combined with histological evaluation, matrixassisted laser desorption/ionization (MALDI) imaging, becomes a highly valuable tool in disease investigation.

Lectures aiming at acquiring competitive skills were also given: Joost Schanstra (France) presented an interesting approach of business SWOT analysis, as applied to personal skills assessment and career planning. Next, Goce Spasovski presented the complex subject of ethics in science that was followed by a very lively discussion among the audience. Ethical guidelines for medical research that are described in the Declaration of Helsinki and the Belmont report cover three fundamental principles: respect for persons, beneficence and justice. It is important to balance the aim of advancement in science with the protection of research subjects as a main priority.

The Regular Meeting included an open to the public session, dedicated to early stage researchers (ESRs). An introductory talk by Giovambattista Capasso (Italy) was given, descrybing the importance of aldosterone in CKD treatment. Aldosterone plays a significant role in the blood pressure regulatory system and hence in the pathogenesis of renal disease. The inhibitors of the renin-angiotensin-aldosterone system (RAAS) and angiotensin-converting enzymes (ACE) have shown renoprotective effects, as the reduction of blood pressure and proteinuria significantly decreases $\mathrm{CKD}$ progression, therefore the blockade of aldosterone pathway should be further investigated with regards to CKD therapy.

Subsequently, trainees within the iMODECKD and BCMolMed projects presented their achievements within the scope of their specific projects, describing current activities, future plans and accomplishments. Briefly, iMODECKD involves a total of 10 ESRs (i.e., Ph.D. students) and 1 ER (Experienced Researcher, i.e., postdoctoral trainee) covering a whole range of topics related to biomarker research in CKD, by application and integration of various "omics" techniques, such as proteomics, metabolomics, transcriptomics, supported by bioinformatics tools and systems biology approaches (Fig. 3). BCMolMed, includes 3 Ph.D. students targeting validation of know bladder cancer biomarkers, comprehensive proteomics analysis of tissue and data integration by the use of systems biology approaches. In all cases significant progress towards achieving the program objectives has been made involving optimization of applied techniques, identification of promising biomarker candidates and development of first versions of CKD and bladder cancer specific databases as well as first disease models based on literature and "omics" data. The ESR session was followed by a discussion about the iMODE-CKD project progress as a whole and future plans related to both the scientific as well as training programs coordinated by Antonia Vlahou.
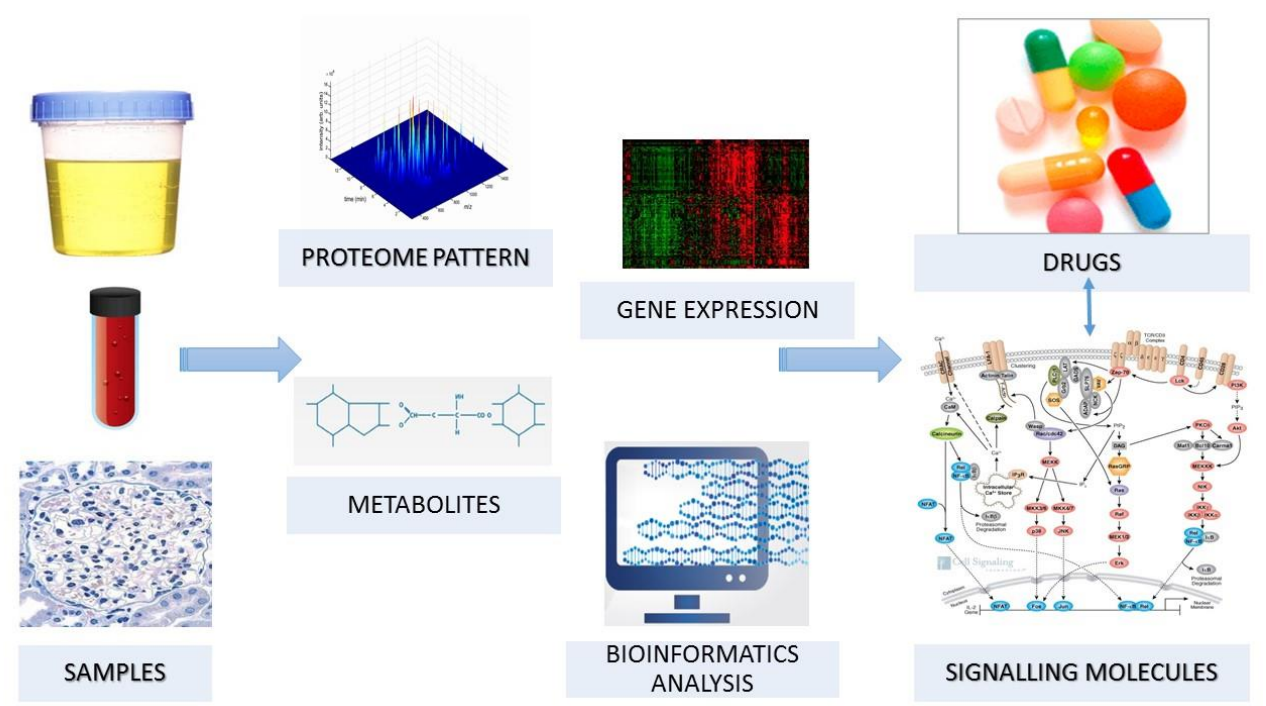

Figure 3-Application of "omics" technologies in biomarker discovery 
The scientific program was complementted by a social program involving working dinners where collaborative projects and students' secondments to partners' laboratories were planned. The next meeting of the consortium is planned for October 1-3, 2015 in Toulouse, France.

Резиме

\section{СООПШТЕНИЕ ОД РАБОТИЛНИЦАТА И РЕДОВНИОТ СОСТАНОК НА ПРОЕКТИТЕ IMODE-CKD И ВСMOLNED ОД ПРОГРАМАТА ЗА ТРЕНИНГ И ИСТРАЖУВАҢЕ „МАРИЈА КИРИ“} (Скопје, март 2015)

\section{Magdalena Krochmal ${ }^{1}$, Katryna Cisek ${ }^{2}$, Katerina Markoska ${ }^{3}$, Goce Spasovski ${ }^{3}$ and Antonia Vlahou ${ }^{1}$}

\footnotetext{
${ }^{1}$ Biotechnology Division, Biomedical Research Foundation Academy of Athens, Soranou Ephessiou 4, 115 27, Athens, Greece ${ }_{2}^{2}$ Mosaiques Diagnostics $\mathrm{GmbH}$, Rotenburger Straße 20, D-30659, Hannover, Germany ${ }^{3}$ University Department of Nephrology, Medical Faculty, Sts. Cyril and Methodius University, Vodnjanska 17, 1000, Skopje, R. Macedonia
}

Од 20 до 22 март 2015 година, во Македонската академија на науките и уметностите (МАНУ) се одржаа работилница и редовен состанок на програмите за обука и истражување на „Марија Кири“ iMODE - CKD (Идентификација на молекуларните детерминанти на утврдената хронична бубрежна болест - ХББ) и BCMolMed (Молекуларна медицина за тумор на мочен меур). Домаќини на состанокот беа центаротучесник Универзитетот „Св. Кирил и Методиј“ во Скопје - Гоце Спасовски и МАНУ - Момир Поленаковиќ (Република Македонија). Претставникот на Истражувачкиот центар за протеомика во МАНУ - Катарина Давалиева (Република Македонија) одржа презентација за протеомските истражувања кај тумор на простата. На состанокот учествуваа 40 научници од 13 различни држави. Работилницата со наслов „Хроничната бубрежна болест: прашања од клиничкиот менаџмент" се состоеше од 15 орални презентации одржани од нефролози и експерти во областа на ХББ. Рејмонд Ванхолдер (Белгиja), поранешен претседател на ERA- EDTA, имаше воведно предавање на тема „ХББ: Прашања што треба да се одговорат, а не се (барем не целосно)“. Работилницата продолжи во четири сесии со предавања на Алберто Ортиз (Шпанија), Оливера Стојчева-Танева (Република Македонија), Димитриос Гоуменос (Грција), Јоаким Бајге (Германија), Марјан Клингер (Полска), Гоце Спасовски (Република Македонија), Јоаким Јанковски (Германија), Адалберт Шилер (Романија), Роберт Џонсон (САД), Франко Ферарио (Италија), Иван Рихлик (Чешка), Фулвио Магни (Италија) и Џовамбатиста Капасо (Италија), сите посветени на тема за обука. Во рамките на состанокот имаше две предавања за комплементарните вештини за етика во науката и напредување во кариерата од двајца главни истражувачи - Гоце Спасовски (Република Македонија) и Јост Шанстра (Франција). За време на редовниот состанок 13 докторанди, односно млади научници и еден искусен научник од двете програми ја презентираа својата работа и напредокот во проектите iMODE-CKD и BCMolMed. Овој состанок беше одлична можност за размена на искуства и идеи во областите на пристапите на системската биологија и транслационата медицина и планирањето на идната соработка.

Клучни зборови: тумор на простата, системска биологија, транслациона медицина, уринарни протеомици. 